\title{
Short Communication: \\ Cave-dwelling Arthropod community of Semedi Show Cave in Gunungsewu Karst Area, Pacitan, East Java, Indonesia
}

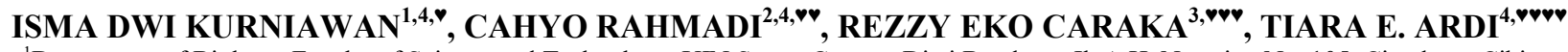 \\ ${ }^{1}$ Department of Biology, Faculty of Science and Technology, UIN Sunan Gunung Djati Bandung. Jl. A.H. Nasution No. 105, Cipadung, Cibiru, \\ Bandung40614, West Java, Indonesia. ”email: ismadwikurniawan@gmail.com \\ ${ }^{2}$ Musem Zoologicum Bogoriense, Indonesian Institute of Science. Jl. Raya Jakarta-Bogor Km. 46, Cibinong Bogor 16911, West Java, Indonesia. \\ "email: cahyo.rahmadi@gmail.com \\ ${ }^{3}$ Department of Statistics, Faculty of Mathematics and Natural Sciences, Universitas Padjadjaran. Jl. Raya Bandung Sumedang Km. 21, Jatinangor, \\ Sumedang 45363, West Java, Indonesia. vwvemail: rezzyekocaraka@gmail.com

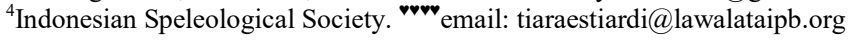

Manuscript received: 8 February 2018. Revision accepted: 19 April 2018.

\begin{abstract}
Kurniawan ID, Rahmadi C, Caraka RE, Ardi TE. 2018. Short Communication: Cave-dwelling Arthropod community of Semedi Show Cave in Gunungsewu Karst Area, Pacitan, East Java, Indonesia. Biodiversitas 19: 857-866. Arthropods are a major group of animals which have significant roles in maintaining cave ecosystem stability. Semedi is a new show cave, but information about arthropods in this cave was not available. The use of cave as a tourist attraction will bring environmental changes which potentially disturb cave-dwelling arthropod community. This study aimed to measure arthropod diversity and their relation to abiotic factors in Semedi Show Cave. Arthropods were sampled by hand collecting, a combination of pitfall and bait traps, and Berlese extractor. Abiotic factors measured were climatic and edaphic parameters. Sampling was conducted in the 3 zones of Semedi cave (Entrance, Twilight, and Dark). Data were analyzed by calculation of richness (Margalef), diversity and evenness (Shannon-Wiener) indices, cluster and correlation analyses. A total 1095 individuals of arthropods consisting of 102 morphospecies, belonging to 6 Classes, and 19 Orders were sampled during this study. The entrance zone had higher richness and diversity indices (richness $=12.80$, diversity $=3.40$ ) than the twilight zone (richness=7.85, diversity=3.25) and the dark zone (richness=5.35, diversity=2.63). Meanwhile, the twilight zone had higher evenness index (0.85) than the entrance zone (0.77) and the dark zone (0.77). Each zone of Semedi cave had different abiotic conditions. Abiotic conditions and Arthropod communities in the twilight and dark zones were more similar to each other than to those of the entrance zone. The statistical analyses showed that there were significant correlations between abiotic factors and arthropod communities. Semedi had various cave-dwelling arthropods. Sustainable management of show cave should be applied to minimize the destructive impact of tourism activities on the cave arthropod community.
\end{abstract}

Keywords: Inventory, cave-dwelling arthropods, sustainable management, show cave

\section{INTRODUCTION}

Cave is a unique environment with relatively stable climatic conditions. This environment is characterized by the permanent absence of light, high air humidity, stable temperature, high $\mathrm{CO}_{2}$ and often limited food resources (Palacious-Vargas et al. 2011; Simoes et al. 2015; Bento et al. 2016). This extreme environmental condition becomes a selective force for many lives so that only particular species can live and thrive in the typical cave environment (Howarth 2009; Romero 2009; Culver and White 2012). Arthropods are the most diverse and abundant group of animals living in cave ecosystem, not only in term of species richness but also in its roles in the ecosystem (Romero 2009). Arthropods can act as predators, decomposers and also food sources for other cave organisms (Suhardjono et al. 2012). Arthropods play critical roles in maintaining cave ecosystem stability (Rahmadi 2002). Disturbance on the Arthropod community in cave ecosystem can disrupt other organisms' life or destroying the entire cave ecosystem.
The threat to cave ecosystem sustainability has increased recently. Besides the impacts of extractive industry activities such as cement and phosphate mines, and pollution, particularly water pollution in caves with underground river systems, the development of caves into tourist attractions (show caves) is also one of the severe threats to cave ecosystem sustainability. Some previous studies indicated that cave development for tourism is identified as one of the major threats to cave biodiversity in particular and ecosystem in general (Macud and Nuneza 2014).

Many new show caves in Indonesia are now being developed. Some caves in Indonesia are even developed into mass tourism. Indeed, currently, show caves in Indonesia are becoming a trend and able to attract many visitors. As an interesting example is Gong cave in Pacitan Regency, East Java that can attract more than 250,000 visitors and contributes more than USD 200,000 per year (Kurniawan et al. 2017). Unfortunately, show caves are often managed to promote economic benefits only, without considering the ecological aspect. Some infrastructures of 
cave often need to be constructed to add attraction and ensure the safety of visitors, but these can change the environmental conditions of the cave. In fact, the cave ecosystem is highly susceptible to disturbances resulting from human activities. If it is damaged, it will be difficult to recover (Fernandez-Cortez et al. 2011; Jones 2016). The damage can even occur before the ecosystem condition of a cave is known, because many show caves are developed without a prior study on ecological aspects.

If the environmental factors are managed properly, utilization of caves as a tourist attraction is an essential aspect of improving the economic level of the local society. The presence of show caves enhances many job opportunities, so it becomes one of the solutions to reduce poverty. Besides, this type of utilization is also considered more sustainable and ecologically friendly.

Developing sustainable show cave requires comprehensive evaluation. So far, evaluation of show caves management in Indonesia has never been conducted. One of the main difficulties in the evaluation process is the lack of data of the initial condition of the cave ecosystem. This condition makes it difficult to know the dynamics of ecosystem changes that occur, so the negative impact of tourism activity on the ecosystem is hard to detect. Research on the initial condition of show caves ecosystem is fundamental to undertake. The availability of secondary data will be a substantial basis for evaluating show caves management.

Semedi is a new show cave located in Gunungsewu karst area, Pacitan Regency, East Java. Gunungsewu has been designated as a Global Geopark Network (GGN
UNESCO) in which conservation is one of the most important aspects that should be considered in every single development in this karst area. Semedi has been developed into a show cave since 2016 and managed by the local society. The construction of infrastructure in the form of electric lights and widening of cave passages had been done. Also, the use of a hazardous chemical substance such as mothballs has been done in this cave. Mothball contains naphthalene, an active compound with toxic effects for insects (Fleming and Baker 1934). Information about the initial ecological condition of Semedi cave about Arthropod community, in particular, was not available yet. Therefore, this study aimed to measure the arthropod diversity and their relation with abiotic factors in Semedi cave. The results of this study are expected to be used as the basic and scientific considerations in the evaluation of Semedi cave management in particular and other show caves in general.

\section{MATERIALS AND METHODS}

This study was conducted at Semedi cave located in Gunungsewu karst area, Indonesia $\left(8.1567^{\circ} \mathrm{S} 111.0256^{\circ} \mathrm{E}\right)$. Samplings were taken during January-February 2017. The cave was divided into three communities, determined based on cave zones: entrance, twilight and dark zones (Culver and White 2005). Semedi has simple cave system with two entrances to make zone condition repeated. Semedi location and passage conditions can be seen in Figure 1.

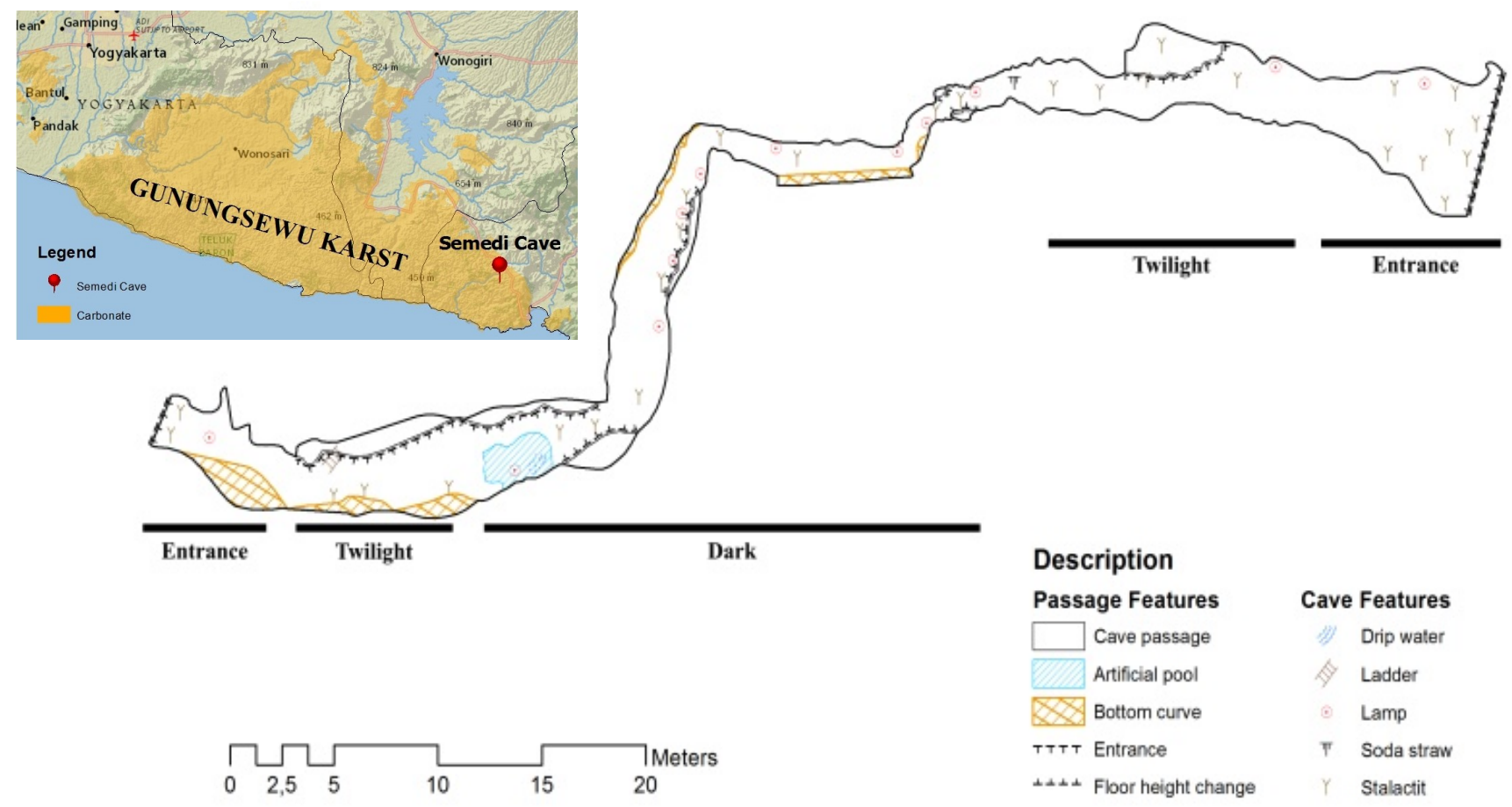

Figure 1. The location of Semedi Cave in Gunungsewu karst area, southern Java, Indonesia (left) and Semedi's Passage Conditions (right) 


\section{Arthropods sampling}

Arthropods were sampled by hand collection (direct collection), pitfall and baits traps, and soil extraction with modified Berlese extractor. The direct collection made with the help of gloves, brushes, and tweezers for 90 minutes (30 minutes x 3 observers) in each zone. Pitfall traps were made by vial bottles ( $5 \mathrm{~cm}$ in diameter) filled with $96 \%$ alcohol and glycerin (9:1 in ratio), while the bait traps were based on Hunt and Millar (2001) design with cheese bait. Pitfall traps were installed in each zone, 5 pieces each, while the bait traps were two pieces and left for 48 hours. The modified Berlese extractor used $15 \mathrm{~W}$ bulb lamps and was placed $20 \mathrm{~cm}$ above the samples. For each zone, two soil samples, each of which was one liter, were taken and extracted for 4-6 days. All collected Arthropods were identified based on morphological characters to the lowest possible taxon level.

\section{Abiotic sampling}

Abiotic measurements included climatic and edaphic factors. Climatic factor measurement was performed directly in the field. Light intensity was measured using lux meter (Lutron LX-107), air temperature and humidity using logger (eTemperature version 8.31), while $\mathrm{CO}_{2}$ level using $\mathrm{CO}_{2}$ meter (Telaire T7001). The edaphic factor measured was soil temperature, carried out directly in the field using soil thermometers. Besides, soil samples were collected and tested in the laboratory of the Agency for Agricultural Research and Development in Yogyakarta to measure the content of soil organic carbon (SOC), nitrogen (N), phosphate $(\mathrm{P})$, soil $\mathrm{pH}$, and moisture. Soil moisture measurement was based on wet and dry weight.

\section{Data analyses}

The data were analyzed by calculating richness index according to Margalef:

$$
\text { D : } \frac{(S-1)}{\ln N} \quad \text { (Dao-Hong 2007) }
$$

Diversity and evenness indices according to ShannonWienner:

$$
\begin{aligned}
& \mathrm{H}^{\prime} \quad:-\sum_{i=1}^{n} P i \ln P i \quad(\text { Schowalter 2011) } \\
& \mathrm{E}_{\mathrm{H}}: \frac{H^{\prime}}{\ln S} \quad \text { (Pielou 1966) }
\end{aligned}
$$

Besides, we also used cluster analyses using MVSP version 3.1 to determine the similarities among communities. Statistical analysis was taken through correlation analysis using SPSS version 24 to know the correlation between abiotic factors and Arthropod communities.

\section{RESULTS AND DISCUSSION}

\section{Arthropods taxa}

A total of 1.095 individuals of Arthropod distributed among six classes, 19 orders, and 102 morphospecies were collected during this study. The list of Arthropod taxa is presented in Table 1.

As seen in Figure 2, Insecta is the most diverse class with the most significant number of individuals. This class is known to be highly adaptive to new environments and environmental changes (Gillot 2005). This capability makes it the most dominant group both in terms of diversity and abundance in all types of ecosystems, including cave ecosystems. Insecta also plays diverse roles in the ecosystem. There are three primary functions of this class. As predators such as the member of Hymenoptera, Coleoptera (Staphylinidae, Cucujidae, and Anthicidae), Dermaptera, and Diplura; as decomposers such as the member of Blattodea, Orthoptera, Diptera, Psocoptera, Coleoptera (Scolytidae and Tenebrionidae), and immature insect group (larvae); and as herbivore such as Orthoptera.

Arachnida has the second diverse of morphospecies and number of individuals after Insecta. Members of this class are dominated by Acari (mites) and Aranea (Spiders). Acari is mostly concentrated around the organic matter piles in the form of bat guano and acts as decomposers, and some are known to act as predators. Other Arachnida members Aranea, Amblypigi, and Opiliones, all serve as predators.

Collembola has the third diverse of morphospecies and number of individuals. Collembola is separated from Insecta and has become a different class. This separation is based on the structure of the ventral tube in the first segment of ventral collembolan abdomen (Suhardjono et al. 2012). Members of this class are known as the essential decomposer in cave ecosystem. The other three classes Diplopoda, Crustacea, and Chilopoda, have relatively fewer morphospecies and individuals than the other three classes described before. Diplopoda (Spirostreptida: Cambalopsidae and Harpagophoridae) and Crustacea (Isopoda: Oniscidae and Philosciidae) serve as decomposers, while Chilopoda (Geophilomorpha: Mecistochepalidae) acts as a predator.

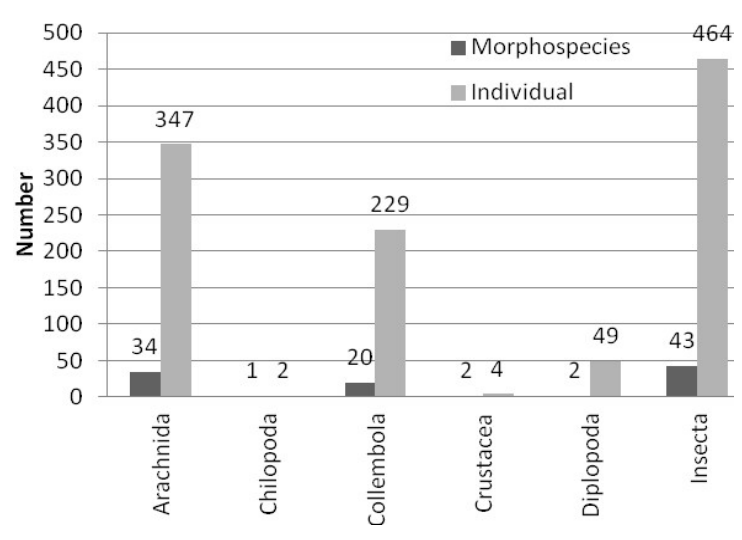

Figure 2. Comparison of species numbers and individuals among classes of Arthropod in Semedi Cave, Gunungsewu karst area, Indonesia 
Table 1. The list of morphospecies in Semedi Cave, Gunungsewu karst area, Indonesia

\begin{tabular}{|c|c|c|c|c|}
\hline Class & Order & Morphospecies & Cave adaptation category & Role in ecosystem \\
\hline \multirow[t]{34}{*}{ Arachnida } & \multirow[t]{16}{*}{ Acari } & Acari sp.1 (Mesostigmata) & Troglophile & Decomposer \\
\hline & & Acari sp.2 (Oribatida) & Troglophile & Predator \\
\hline & & Acari sp.3 (Oribatida) & Troglophile & Predator \\
\hline & & Acari sp.4 (Oribatida) & Troglophile & Predator \\
\hline & & Acari sp.5 (Mesostigmata) & Troglophile & Decomposer \\
\hline & & Acari sp.6 (Gamasida: Uropodidae) & Troglophile & Decomposer \\
\hline & & Acari sp.7 (Oribatida) & Troglophile & Predator \\
\hline & & Acari sp. 8 (Mesostigmata) & Troglophile & Decomposer \\
\hline & & Acari sp.9 & Troglophile & Decomposer \\
\hline & & Acari sp. 10 & Troglophile & Decomposer \\
\hline & & Acari sp.11 (Prostigmata) & Troglophile & Decomposer \\
\hline & & Acari sp.12 & Troglophile & Decomposer \\
\hline & & Acari sp.13 & Troglophile & Decomposer \\
\hline & & Acari sp.14 (Prostigmata) & Troglophile & Decomposer \\
\hline & & Acari sp.15 & Troglophile & Decomposer \\
\hline & & Acari sp.16 (Prostigmata) & Troglophile & Decomposer \\
\hline & Amblypygi & Charotidae (Charon sp.) & Troglophile & Predator \\
\hline & \multirow[t]{16}{*}{ Aranea } & Aranea sp.1 & Troglophile & Predator \\
\hline & & Aranea sp. 2 & Troglophile & Predator \\
\hline & & Aranea sp. 3 & Troglophile & Predator \\
\hline & & Aranea sp. 4 & Troglophile & Predator \\
\hline & & Aranea sp. 5 & Troglophile & Predator \\
\hline & & Aranea sp.6 & Troglophile & Predator \\
\hline & & Araneidae sp.1 & Troglophile & Predator \\
\hline & & Araneidae sp.2 & Troglophile & Predator \\
\hline & & Salticidae sp.1 & Troglophile & Predator \\
\hline & & Salticidae sp.2 & Troglophile & Predator \\
\hline & & Salticidae sp.3 & Troglophile & Predator \\
\hline & & Scytodidae sp. 1 & Troglophile & Predator \\
\hline & & Scytodidae sp. 2 & Troglophile & Predator \\
\hline & & Oxyopidae & Accidental & Predator \\
\hline & & Theridiidae sp. 1 & Troglophile & Predator \\
\hline & & Theridiidae sp. 2 & Troglophile & Predator \\
\hline & Opiliones (Laniatores) & Assamiidae & Troglophile & Predator \\
\hline Chilopoda & Geophilomorpha & Mecistochepalidae & Troglophile & Predator \\
\hline \multirow[t]{20}{*}{ Collembola } & \multirow[t]{16}{*}{ Entomobryomorpha } & Paronellidae (Ascocyrtus sp.) & Troglophile & Decomposer \\
\hline & & Paronellidae (Salina sp.1) & Troglophile & Decomposer \\
\hline & & Paronellidae (Salina sp.2) & Troglophile & Decomposer \\
\hline & & Paronellidae sp. & Troglophile & Decomposer \\
\hline & & Cyphoderidae sp.1 & Troglophile & Decomposer \\
\hline & & Cyphoderidae sp.2 & Troglophile & Decomposer \\
\hline & & Cyphoderidae (Mimocerus sp.) & Troglophile & Decomposer \\
\hline & & Entomobryidae (Entomobrya sp.) & Troglophile & Decomposer \\
\hline & & Entomobryidae (Siera sp.) & Troglophile & Decomposer \\
\hline & & Entomobryidae sp. & Troglophile & Decomposer \\
\hline & & Entomobryidae (Arcocyrtus sp.) & Troglophile & Decomposer \\
\hline & & Entomobryidae (Ascocyrtus sp.) & Troglophile & Decomposer \\
\hline & & Isotomidae (Folsomides sp.1) & Troglophile & Decomposer \\
\hline & & Isotomidae (Folsomides sp.2) & Troglophile & Decomposer \\
\hline & & Tomoceridae sp. 1 & Troglophile & Decomposer \\
\hline & & Tomoceridae sp.2 & Troglophile & Decomposer \\
\hline & \multirow[t]{2}{*}{ Poduromorpha } & Hypogastruridae (Hypogastrura sp.) & Troglophile & Decomposer \\
\hline & & Neanuridae & Troglophile & Decomposer \\
\hline & \multirow[t]{2}{*}{ Symphypleona } & Symphypleona sp.1 & Troglophile & Decomposer \\
\hline & & Symphypleona sp.2 & Troglophile & Decomposer \\
\hline \multirow{2}{*}{ Crustacea } & \multirow{2}{*}{ Isopoda } & Oniscidae & Troglobite & Decomposer \\
\hline & & Philosciidae & Troglophile & Decomposer \\
\hline \multirow[t]{2}{*}{ Diplopoda } & \multirow[t]{2}{*}{ Spirostrepsida } & Trachyjulus tjampeanus & Troglophile & Decomposer \\
\hline & & Harpagophoridae & Troglophile & Decomposer \\
\hline \multirow[t]{4}{*}{ Insecta } & \multirow[t]{2}{*}{ Blattodea } & Blaberidae & Troglophile & Decomposer \\
\hline & & Blattidae & Troglophile & Decomposer \\
\hline & \multirow[t]{2}{*}{ Coleoptera } & Anthicidae & Troglophile & Predator \\
\hline & & Cucujidae sp.1 & Troglophile & Decomposer \\
\hline
\end{tabular}




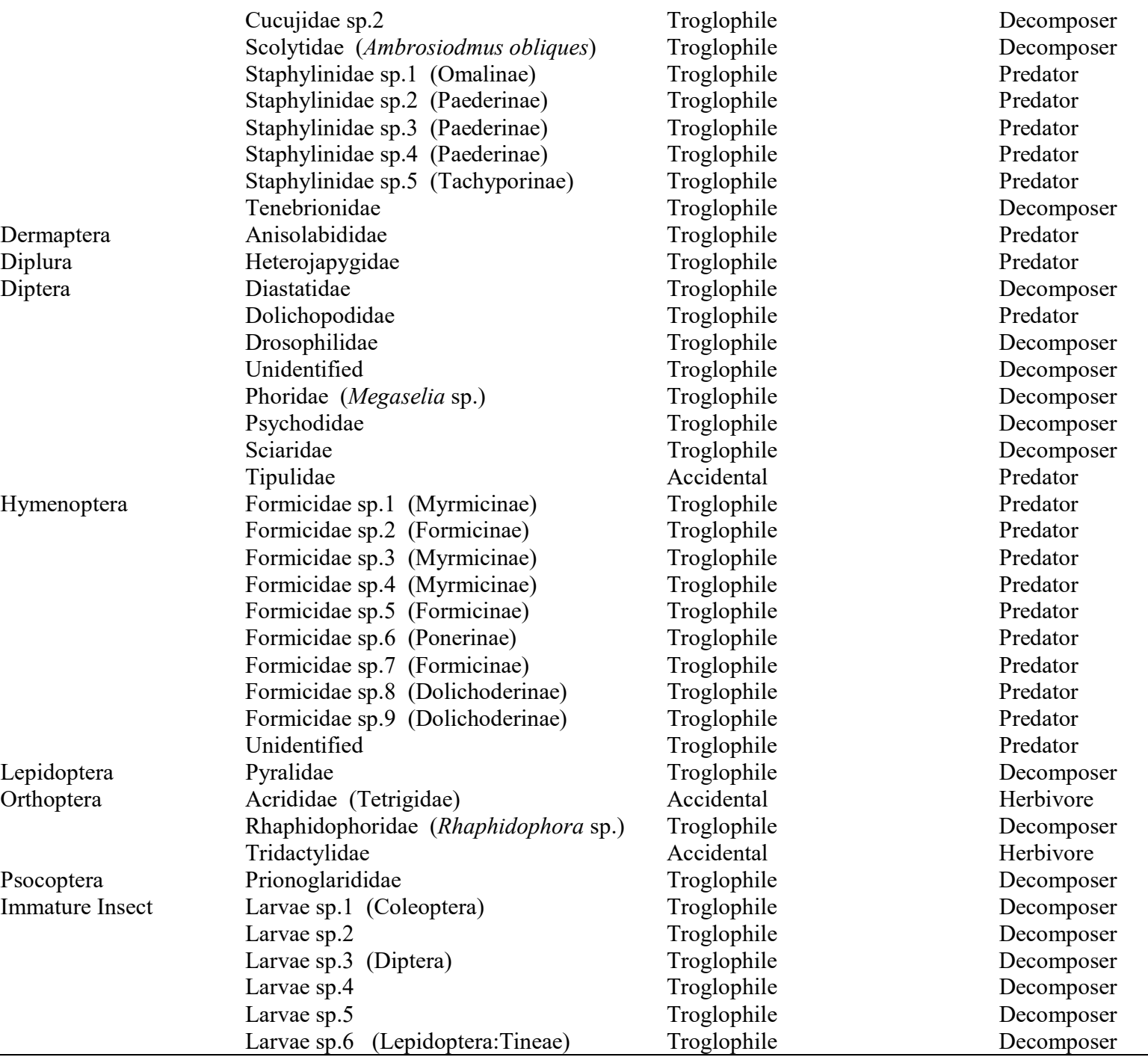

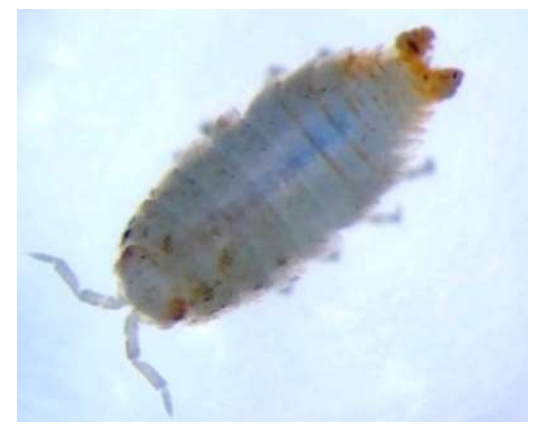

Figure 3. Troglobitic Isopod (Family: Oniscidae)

Based on morphological characters exhibited by the 102 arthropods species found in this study, there was only one species that is considered as troglobites (obligate cave species), it is Isopod from the Family of Oniscidae (Figure 3 ). The troglobite Isopod shows the troglomorphic features in the form of depigmentation and reduction of eyes size (Culver and Pipan 2009). Only two individuals of this species were successfully collected, and both were found in the guano piles. Cave fauna classified as troglobite is known to have a small population size and vulnerable to extinction (Suhardjono 2011). One of the main considerable factors that allegedly cause the low number of troglobitic species in the Semedi cave is the relatively short cave passage. The biota present in this cave has not been completely isolated from the outside environment of the cave.

Most of the species of arthropods found in this study belong to troglophile (97 species), while a few others are classified as accidental (4 species). Some other species also show the troglomorphic features, for examples elongated antennae and or legs on cave cricket (Rhaphidophora sp.) and whip spider (Charon sp.), also eye reduction and depigmentation on Collembola (Fam. Cyphoderidae), but those species are not considered as obligate cave dwellers. Those species are commonly found in caves, but they can also be found in some other habitats that have nearly resemble characters of caves (troglophile). Culver and White (2005) explain that not all traits showing troglomorphy are cave-adapted, but cave-adapted is always troglomorphy. It means that the morphological characters such as elongated antennae and or legs, depigmentation, and reduction of eyes can also be owned by fauna that lives outside cave environment. 


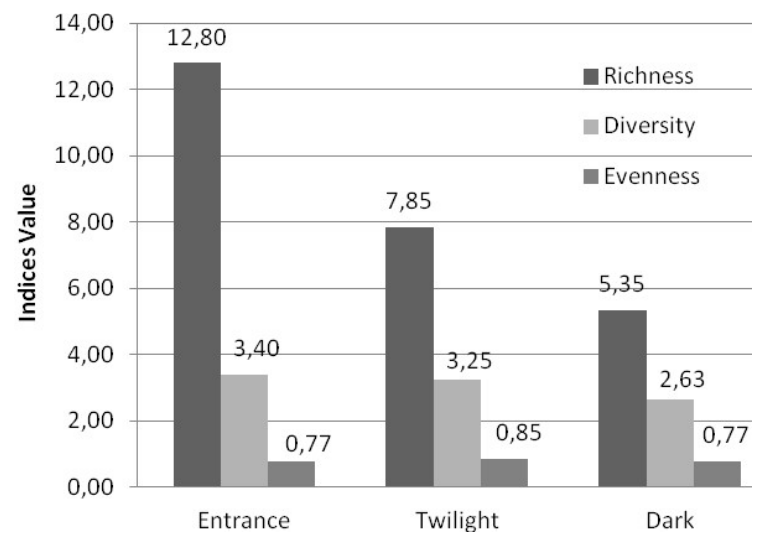

Figure 4. The indexes of richness, diversity, and evenness Arthropod in Semedi Cave, Gunungsewu karst area, Indonesia

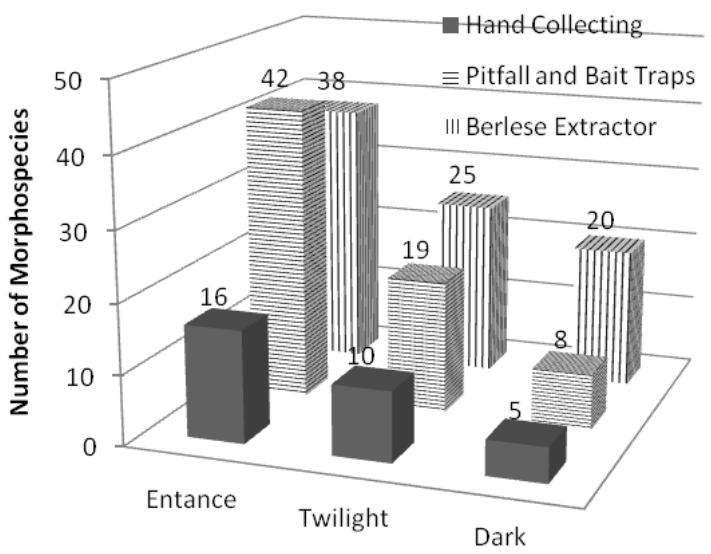

Figure 5. Difference on species number among different sampling techniques

As seen in Figure 4, richness index shows that the entrance zone had the highest species richness, followed by the twilight zone and the dark zone. This condition is also supported by the data from the use of three different sampling techniques in this study that showed a uniform pattern. The entrance zone always had the highest species richness, followed by the twilight and dark zones (Figure 5). These results simultaneously demonstrate that the use of a combination of several sampling techniques is essential for obtaining representative data. Each sampling method has its advantages and disadvantages. The combination of several sampling techniques will produce complement data.

The diversity index (Figure 4) shows a pattern similar to the richness index. These results illustrate that the entrance and twilight zones had higher species richness and ecosystems in these zones tended to be more stable and resistant to damage than the dark zone. The low value of diversity index in dark zone indicates that arthropod communities in this zone had a higher ecological pressure and less stable than the entrance and twilight zones. Typical environmental conditions require organisms to adapt and survive in the dark zone that has the extreme environment. Therefore, the dark zone is dominated by species that have successfully adapted to life in this zone (Suhardjono et al. 2012).

Evenness index shows that the population of each arthropod in the twilight zone was evenly distributed, while the entrance and dark zones tended to be similar that there were some species that slightly dominated. The species found to have population dominating in the entrance zone were ants (Sub Fam. Dolichoderinae, Myrmicinae), spiders (Fam. Uloboridae), Collembola (Ascocyrtus sp, Folsomides sp.), larvae (Coleoptera), and Acari (Oribatidae). While some species that dominated in the dark zone were a millipede (Trachyjulus tjampeanus), cave cricket (Rhaphidophora sp.), Collembola (Ascocyrtus sp, Folsomides sp, Fam. Cyphoderidae), ants (Sub Fam. Formicinae), acari (Mesostigmata and Oribatida) and insect larvae.

\begin{abstract}
Abiotic parameter
There were differences in the climatic conditions among cave zones. Light intensity decreased with increasing distance from the cave entrance. The entrance zone had the highest light intensity due to direct exposure to sunlight. There was a significant decrease of light intensity in the twilight zone because the light reaching to this zone was only reflected light from the entrance zone. The dark zone had dark conditions with 0 lux of light intensity. Darkness without light is one of the leading typical characteristics of cave environment (Gunn 2004; Culver and White 2005). Although some electric lights have been installed in the dark zone of Semedi cave, the lights were completely turned off during sampling periods.

The level of air $\mathrm{CO}_{2}$ showed a pattern opposite to the light intensity. $\mathrm{CO}_{2}$ tended to increase as the distance from the cave entrance increased. Relative humidity (RH) showed the same pattern as $\mathrm{CO}_{2}$. The dark zone had the highest $\mathrm{RH}$, followed by the twilight zone and the entrance zone. The high $\mathrm{CO}_{2}$ level and $\mathrm{RH}$ are also known as typical characters of cave environment (Palacious-Vargas et al. 2011; Simoes et al. 2015; Bento et al. 2016). Meanwhile, an average of air temperature did not show any significant difference among cave zones. All three zones had an average temperature of $24-24.5^{\circ} \mathrm{C}$. The differences in the air temperature among zones can be seen on the data of air temperature dynamics presented in Figure 5.
\end{abstract}

Table 2. Climatic measurement in Semedi Cave, Gunungsewu karst area, Indonesia

\begin{tabular}{lcccc}
\hline Zone & $\begin{array}{c}\text { Light intensity } \\
(\mathbf{l u x})\end{array}$ & $\begin{array}{c}\mathbf{C O}_{\mathbf{2}} \\
(\mathbf{p p m})\end{array}$ & $\begin{array}{c}\text { RH } \\
(\mathbf{\%})\end{array}$ & $\begin{array}{c}\text { Temp. } \\
\left({ }^{\circ} \mathbf{C}\right)\end{array}$ \\
\hline Entrance & 1575.14 & 393.48 & 94.28 & 24.49 \\
Twilight & 7.15 & 400.60 & 98.34 & 24.01 \\
Dark & 0.00 & 425.20 & 100.44 & 24.10 \\
\hline
\end{tabular}




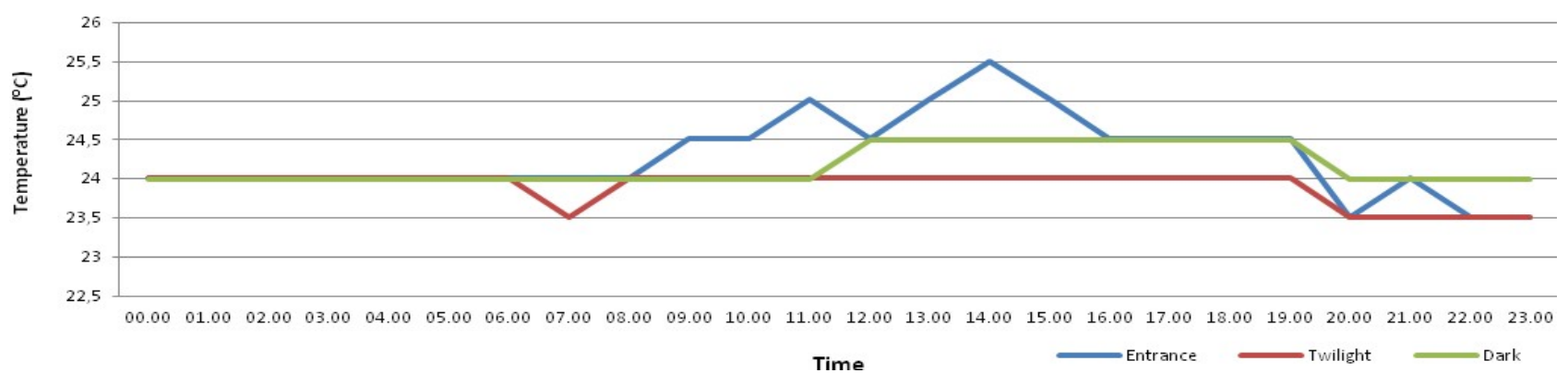

Figure 6. Air temperature dynamics in Semedi Cave, Gunungsewu karst area, Indonesia

As seen in Figure 6, the air temperature in entrance zone tended to fluctuate quickly. This zone is a right border between cave environments with outside environments. Outside cave conditions strongly influenced the temperature conditions in this zone so makes it highly fluctuated. A slightly different condition occurred in the twilight zone. The air temperature in this zone much less fluctuated than the entrance zone. This zone has transition characters between the fluctuating entrance zone and the stable of dark zone. The dark zone is known to have much more stable environmental conditions (Culver and White 2005). This means that there should be no significant changes in air temperature inside the dark zone.

There was $0.5^{\circ} \mathrm{C}$ increment of air temperature in the dark zone (Figure 6) from the original $24^{\circ} \mathrm{C}$ to $24.5^{\circ} \mathrm{C}$ at $12: 00$ and the temperature lasted until 19:00 ( 8 hours). After 19.00 , the air temperature returned to $24^{\circ} \mathrm{C}$. An important note is that team survey consisting seven people began the sampling activities in the dark zone at 11:00 am for approximately 1.5 hours. The temperature increment occurred just after the survey activities had been conducted in the dark zone. This result proves that human activity in the dark zone can increase air temperature. Besides, the cave environment takes a long time to restore the air temperature to its original state (Lario and Soler 2010).

Edaphic measurements also showed the differences result among cave zones. Soil $\mathrm{pH}$ in the twilight and dark zones tended to be more acidic than entrance zone. Also, $\mathrm{P}_{2} \mathrm{O}_{5}$ in the twilight and dark zones was also higher. Both zones had the same organic material in the form of insectivorous bat guano. Guano is known to have low $\mathrm{pH}$ and contains high organic carbon, phosphate, and nitrogen (Sikazwe and Waele 2004). The content of SOC and N-NH4 in the dark zone was lower than either the twilight or the entrance zone. This condition happens because the number and variation of organic matter in the dark zone are relatively fewer than entrance and twilight zones. The limited number and variety of organic matter that is the food source for biota is one of the typical characteristics of cave environment (Gun 2004). Soil moisture tended to be higher in twilight and dark zones. Percolate water droplets that fell into the ground make the soil moisture higher. Soil temperatures tended to be higher in entrance zone. Soil temperature is known to have a negative correlation with soil moisture. This means that the higher soil temperature will decrease soil moisture (Pinheiro et al. 2001).

\section{Dissimilarity among communities}

Based on the result of cluster analysis (Figure 7), it can be seen that the twilight zone community tended to be more similar with the dark zone community, whereas entrance zone tended to be different. Bray-Curtis's dissimilarity index was used as a basis for the establishment of the dendrogram. This index is considered more efficient and appropriate for ecological analysis because its calculation is not only based on the presence or absence of a species in the community but also the number of individuals of each species (Schowalter 2011). This cluster analysis result means that the community's similarity between twilight and dark zones was not only from the species composition aspect but also from the population of each species in those communities.

Table 3. Edaphic measurement in Semedi Cave, Gunungsewu karst area, Indonesia

\begin{tabular}{lcccccc}
\hline Zone & $\mathbf{p H}$ & $\begin{array}{c}\text { SOC } \\
(\mathbf{\%})\end{array}$ & $\begin{array}{c}\mathbf{N}^{-N_{4}} \\
(\mathbf{p p m})\end{array}$ & $\begin{array}{c}\mathrm{P}_{2} \mathrm{O}_{5} \\
(\mathbf{p p m})\end{array}$ & $\begin{array}{c}\text { Moist. } \\
(\mathbf{\%})\end{array}$ & $\begin{array}{c}\text { Temp. } \\
\left({ }^{\circ} \mathbf{C}\right)\end{array}$ \\
\hline Entrance & 7.51 & 0.75 & 145.53 & 26 & 20.66 & 25.95 \\
Twilight & 6.54 & 1.59 & 203.74 & 189 & 26.63 & 25.08 \\
Dark & 6.82 & 0.46 & 66.94 & 128 & 26.68 & 24.80 \\
\hline
\end{tabular}

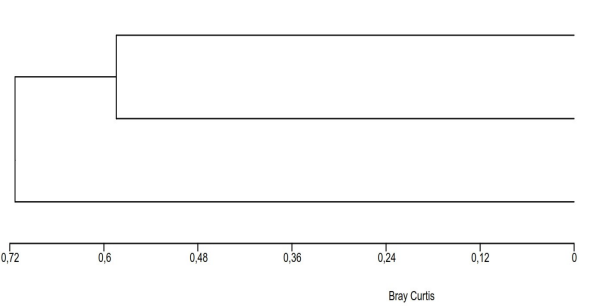

Dark zone

Twilight zone

Entrance zone

Figure 7. Dissimilarity of Arthropod community among cave zones in Semedi Cave, Gunungsewu karst area, Indonesia

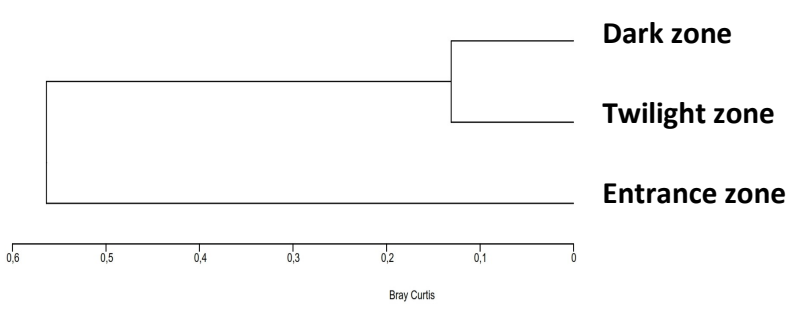

Figure 8. Dissimilarity of abiotic parameters among cave zones in Semedi Cave, Gunungsewu karst area, Indonesia 
Cluster analysis of abiotic factors was also taken to know which zones had more similar abiotic condition to each other. As seen in Fig. 8, the abiotic condition of twilight and dark zones tended to resemble each other compared to the entrance zone. The presence of biota cannot be separated from the surrounding abiotic condition. The abiotic conditions determine and influence the existence and sustainability of biotic components in ecosystems. The higher abiotic similarity between twilight and dark zones made the arthropod communities in these zones more similar (Figure 7).

Statistical analysis through correlation test was done to find out the correlation between abiotic components with the arthropod communities structure. Nonparametric analysis was chosen because the abiotic sample size was so small. The correlation test results can be seen in Table 4 .

Based on Table 4, it can be seen that there are robust and significant correlations between the climatic and edaphic factor components with the arthropod community structure. Light intensity and air temperature were positively correlated with richness $(r=0.94$ and $r=0.87)$. The entrance zone that had a higher light intensity and air temperature than the other two zones also had the highest species richness. Light is the main source of energy for life. The existence of light allows plants (producers) to live and produce primary productivity (organic matter) through photosynthesis. Primary productivity is the source of biodiversity at higher trophic levels in ecosystems (Culver and White 2005). The absence of sunlight in the dark zone makes the species richness in this zone limited.

Two other components of the climatic factor of the $\mathrm{CO}_{2}$ level and air humidity had negative correlations with the three indicators of the structure of arthropod community. $\mathrm{CO}_{2}$ was strongly negatively correlated with richness $(\mathrm{r}=$
$0.88)$, diversity $(\mathrm{r}=-0.00)$, and evenness $(\mathrm{r}=-0.83)$, whereas air humidity was strongly negatively correlated with richness $(\mathrm{r}=-1.00)$ and diversity $=-0.86)$ and moderately negatively correlated with evenness $(\mathrm{r}=-0.47)$. The dark zone had a higher $\mathrm{CO}_{2}$ level and air humidity than the other 2 zones, but it had the lowest species richness, and there were some species with dominant populations (low evenness) such as millipede Trachyjulus tjampeanus, springtails Ascocyrtus sp, Folsomides sp, Fam. Cyphoderidae, cave cricket Rhaphidophoridae sp, Acari (Oribatidae), ant and insect larvae.

Table 4. Correlation among abiotic components with the arthropod communities in Semedi Cave, Gunungsewu karst area, Indonesia

\begin{tabular}{llll}
\hline Variables & Richness & Diversity & Evenness \\
\hline Climatic & $\mathbf{r}$ & & \\
Light Intensity & $0.94^{\# \# \#}$ & 0.65 & 0.15 \\
$\mathrm{CO}_{2}$ & $-0.88^{* * *}$ & $-1.00^{* * *}$ & $-0.83^{* * *}$ \\
Air Temperature & $0.87^{\# \# \#}$ & 0.50 & -0.03 \\
Air Humidity & $-1.00^{* * *}$ & $-0.86^{* * *}$ & -0.47 \\
& & & \\
Edaphic & $\mathbf{r}$ & & \\
pH & $0.81^{\# \# \#}$ & 0.40 & -0.14 \\
$\mathrm{SOC}$ & 0.07 & 0.56 & $0.91^{\# \#}$ \\
$\mathrm{NNH}_{4}$ & 0.42 & $0.82^{\# \# \#}$ & $1.00^{\# \#}$ \\
$\mathrm{P}_{2} \mathrm{O}_{5}$ & $-0.75^{* * *}$ & -0.31 & 0.23 \\
Soil Temperature & $0.99^{\# \# \#}$ & $0.80^{\# \# \#}$ & 0.37 \\
Soil Mositure & $-0.94^{* * *}$ & -0.65 & -0.15 \\
\hline
\end{tabular}

Note: $\mathrm{r}=$ coeficient of correlation, $* * *$ Very strong correlation (negative) and significant on $\alpha=5$, \#\#\# Very strong correlation (positive) and significant on $\alpha=5$

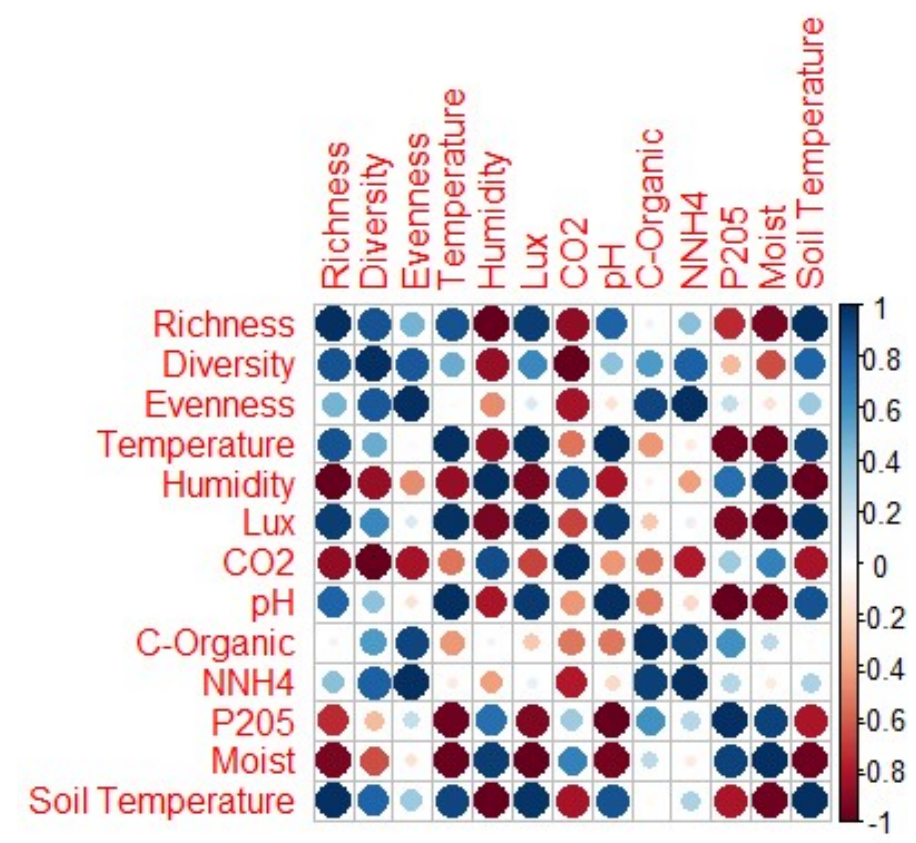

Figure 9. Correlation among measured variables in Semedi Cave, Gunungsewu karst area, Indonesia 
The correlation test of the edaphic factor components showed that soil $\mathrm{pH}, \mathrm{SOC}, \mathrm{NNH}_{4}$, and soil temperature had strong positive correlations with the arthropod community. $\mathrm{pH}$ was positively correlated with richness $(\mathrm{r}=0.81)$ meaning that zones with higher soil $\mathrm{pH}$ (alkali), had relatively higher species richnesses. The entrance zone had the highest $\mathrm{pH}$ and also had the highest species richness. The twilight and dark zones had much organic matter in the form of bat guano and had relatively low $\mathrm{pH}$. Every soil organism has an optimum $\mathrm{pH}$ and a tolerance limit to different soil pH (Lavelle et al. 1995). Arthropod species that live in the twilight and dark zones are thought to be more tolerant to acidic environmental conditions.

SOC was highly positively correlated with evenness ( $\mathrm{r}$ $=0.91)$. This means that each population of Arthropods tends to be more similar (low dominance) in zones with high soil SOC content such as in the twilight zone. SOC is an organic material that plays a significant role as a source of food for Arthropods. The twilight zone had the highest SOC content, but the species richness in this zone was not so high as the entrance zone. Diversity is not necessarily determined solely by the quantity of sources of organic matter, but also the quality of the organic matter. The heterogeneity of food sources is one of the most important quality indicators (Culver and White 2005). The twilight zone had the highest organic content, but the variety of organic material was low, consisting mostly of bat guano. The limited species of Arthropods capable of using guano as food causes of species richness in this zone lower than the bright zones.

Soil temperature was positively correlated with richness $(r=0.99)$ and diversity $(r=0.80)$. Soil temperature is known to have a strong positive correlation with the air temperature. This condition occurs because of the process of heat flow and energy balancing between those two elements (Zheng et al. 1993; Islam et al. 2015). Both, soil temperature and air temperature had strong positive correlations with diversity. The entrance zone with the highest soil temperature and air temperature had the highest diversity. Soil temperature and air temperature have a strong positive correlation with light intensity. High soil temperature and air temperature in entrance zone are the effects of direct sun exposure. The presence of sunlight further allows the life of green plants to allow many types of Arthropods to live. This is what causes these two components to be positively correlated with diversity.

$\mathrm{NNH}_{4}$ was positively correlated with evenness ( $\mathrm{r}=$ $1.00)$ and diversity $(\mathrm{r}=0.82)$. The entrance and twilight zones that had high $\mathrm{NNH}_{4}$ soil content had higher diversity and evenness than the dark zone. $\mathrm{NNH}_{4}$ is known to have no direct effect on Arthropods because the form of nitrogen in the soil cannot be used directly by Arthropods. Nitrogen induces the Arthropod community indirectly by determining the quality of tissue and vegetation productivity. Vegetation conditions will then affect the Arthropod community living in the environment. Similar to $\mathrm{NNH}_{4}, \mathrm{P}_{2} \mathrm{O}_{5}$ is also known to have no direct effect on the Arthropod community (Parwez and Sharma 2014). Based on the correlation test, this component had a very strong negative correlation with richness $(r=-0.75)$. The twilight and dark zones had higher $\mathrm{P}_{2} \mathrm{O}_{5}$ content than entrance zone, but species richness in these zones was lower. The existence of guano is a factor that can explain this relationship. Guano is known to have a high content of $\mathrm{P}_{2} \mathrm{O}_{5}$ (Sikazwe and De Waele 2004). The twilight and dark zones had organic matter in the form of guano, so the $\mathrm{P}_{2} \mathrm{O}_{5}$ content was relatively high. However, species richness in those zones was lower than that in the entrance zone.

Soil moisture had a very strong negative correlation with richness $(r=-0.94)$. The twilight and dark zones had higher soil moisture than the entrance zone, but species richness in these zones was relatively lower. These zones tended to be populated by common species in cave ecosystems as the dominant species. Some species that dominated these zones were the decomposers that lived around bat guano. Moisture allows the growth of fungi and other microbes that are main food for decomposer Arthropods (Parwez and Sharma 2014).

\section{Conclusions}

A total of 1,095 individuals of Arthropod distributed among six classes, 19 orders, and 102 morphospecies were found in Semedi cave. Insecta had the highest species richness (43 species), followed by Arachnida (34 species), Collembola (20 species), Diplopoda and Crustacea (2 species of each), and Chilopoda (1 species). The entrance zone had the highest species richness, followed by the twilight and dark zones. Abiotic conditions and arthropod community structures in twilight and dark zones tended to have high similarity compared to those of the entrance zone. Abiotic factors determine the structure of arthropod community in each cave zone. Light intensity, air temperature, soil $\mathrm{pH}, \mathrm{SOC}, \mathrm{NNH}_{4}$, and soil temperature had high positive correlations with the Arthropod community, whereas air $\mathrm{CO}_{2}, \mathrm{RH}$, soil $\mathrm{P}_{2} \mathrm{O}_{5}$, and soil moisture had negative correlations. Semedi had various cave-dwelling arthropods. Changes in environmental conditions due to tourism activities can threaten the survival of the Arthropod communities inside it. Sustainable management of show cave should be applied to minimize the destructive impact of tourism on Semedi cave arthropod community.

\section{ACKNOWLEDGEMENTS}

We thank colleagues in Biospeleology Studdien Gruppen (BSG UNY), Yogyakarta, Indonesia and Indonesian Speleological Society (ISS) for their help in field work, to colleagues in Museum Zoologicum Bogoriense, Indonesian Institute of Science (LIPI), Bogor, Indonesia for help in identification. We express our gratitude to the manager of Semedi Show Caves and residents for permission to conduct this study. Last but not the least is exceptional thanks to Indonesia Endowment Fund for Education (LPDP) for the financial support. 


\section{REFERENCES}

Bento DDM, Ferreira RL, Prous X, Souza-Silva M, Bellini BC, Vasconcellos A. 2016. Seasonal variations in cave invertebrate communities in the Semiarid Caatinga, Brazil. J Caves and Karst Studies 78 (2): 61-71.

Culver DC, Pipan T. 2009. The Biology of Caves and Other Subterranean Habitats. Oxford University Press, New York.

Culver DC, White W B. 2005. Encyclopedia of Caves. Elsevier, USA.

Culver DC, White WB. 2012. Encyclopedia of Caves. 2nd ed. Elsevier, USA.

Dao-Hong Li. 2007. Correlation between the animal community structure and environmental factors in Jialiang and Boduo Caves of Guizhou Province, China. Acta Ecologica Sinica 27 (6): 2167-2176.

Fernandez-Cortes A, Cuezva S, Sanchez-Moral S, Cañaveras JC, Porca E, Jurado V, Martin-Sanchez PM, Saiz-Jimenez C. 2011. Detection of Human-Induced Environmental Disturbances in a Show Cave. Environmental Science and Pollution Research 18:1037-1045.

Fleming WE, Baker FE. 1934. The Use of Naphthalene Against the Japanese Beetle. Technical Bulletin No. 427. United States Department of Agriculture, Washington DC.

Gillot C. 2005. Entomology. 3rd ed. Springer, Netherlands.

Gunn J. 2004. Encyclopedia of Caves and Karst Science. Routledge Taylor and Francis Group, New York and London.

Howarth FG. 2009. Encyclopedia of Insect: Cave Insect. 2nd ed Elsevier, USA.

Hunt M, Millar I. 2001. Cave Invertebrate Collecting Guide. Department of Conservation, New Zealand.

Islam KI, Khan A, Islam T. 2015. Correlation between atmospheric temperature and soil temperature: A case study for Dhaka, Bangladesh. Atmosph Clim Sci 5: 200-208.

Jones C. 2016. A Guide to Responsible Caving, 5th ed. National Speleological Society. Huntsville, AL.

Kurniawan ID, Rahmadi C, Ardi TE, Nasrullah R, Willyanto MI, Rahayu S. 2017. The Detection of Human Activities' Impact on Show Caves Environment in Pacitan, Indonesia. Proceedings of the 17th International Congress of Speleology, Sydney, NSW, Australia July 22-28, 2017

Kurniawan ID, Soesilohadi RCH, Rahmadi C, Caraka RE, Pardamean B. 2018. The difference on Arthropod communities' structure within show caves and wild caves in Gunung Sewu karst area, Indonesia. Ecol Environ Conserv 24 (1): 81-90.

Lario J, Soler V. 2010. Microclimate Monitoring of Pozalagua Cave (Vizcaya, Spain): Application to Management and Protection of Show Caves. J Cave Karst Stud 72 (3): 169-180.
Lavelle P, Chauvel A, Fragoso C. 1995. Faunal activity in acid soils. In: Date RA (ed.). Proceeding of the Third International Symposium on Plant-Soil Interaction At Low $\mathrm{pH}$ : Principles and Management. Kluwer Academic Publishers, Amsterdam, The Netherlands.

Macud AM, Nuneza OM. 2014. Diversity of cave macro-invertebrates in mighty cave, Tagoloan, Lanao del norte, Philippines. J Biodiv Environ Sci 5 (3): 376-386

Palacious-Vargas JG, Castano-Meneses G, Estrada DA. 2011. Diversity and dynamics of microarthropods from different biotopes of Las Sardinas Cave (Mexico). Subterr Biol 9: 113-126.

Parwez H, Sharma N. 2014. Effect of edaphic factors on the population density of soil microarthropods in agro-forestry Habitat. J Agroecol Nat Resour Manag 1 (3): 187-190.

Pielou EC. 1966. The measurement of diversity in different type of biological collections. J Theor Biol 13: 44-131.

Pinheiro AC, Tucker CJ, Entekhabi D, Privette JL, Berry JA. 2001. Assessing the relationship between surface temperatures and soil moisture in Southern Africa. Remote Sensing and Hydrology 2000 IAHS Publication 267: 296-301.

Rahmadi C. 2002. Keanekaragaman fauna Gua Ngerong, Tuban, Jawa Timur: Tinjauan Khusus pada Arthropoda. Zoo Indonesia Jurnal Fauna Tropika: 19-27. [Indonesian]

Romero A. 2009. Cave Biology, Life in Darkness. Cambridge University Press, UK.

Schowalter TD. 2011. Insect Ecology, An Ecosystem Approach. 3rd ed. Elsevier, USA.

Sikazwe O, de Waele B. 2004. Assesment of the quality and reserves of bat guano at Chipongwe and Kapongo Caves near Lusaka as Fertiliser Material. UNZA J Sci Technol Special Edition June 2004: 32-42.

Simoes MH, Souza-Silva M, Ferreira RL. 2015. Cave physical attributes influencing the structure of terrestrial invertebrate communities in Neotropics. Subterr Biol 16: 103-121.

Suhardjono YR. 2011. Peran Biospeleologi dalam Pengelolaan Kawasan Karst. Cave Ecosystem Workshop, Yogyakarta, 18-19 Oktober 2011. [Indonesian]

Suhardjono YR, Ubaidillah R. 2012. Fauna Karst dan Gua Maros Sulawesi Selatan. Lembaga Ilmu Pengetahuan Indonesia-LIPI, Bogor. [Indonesian]

Suhardjono YR, Deharveng L, Bedos A. 2012. Collembola (Ekorpegas). PT Vega Briantama Vandanesia, Bogor. [Indonesian]

Zheng D, Hunt Jr ER, Running SW. 1993. A daily soil temperature model based on air temperature and precipitation for continental applications. Clim Res 2: 183-191. 